\title{
Chikungunya virus outbreak expansion and microevolutionary events affecting epidemiology and epidemic potential
}

This article was published in the following Dove Press journal:

Research and Reports in Tropical Medicine

30 March 2015

Number of times this article has been viewed

\section{Ann M Powers}

Arboviral Diseases Branch, Division of Vector-Borne Diseases, Centers for Disease Control and Prevention, Fort Collins, CO, USA
Correspondence: Ann M Powers Arboviral Diseases Branch, Division of Vector-Borne Diseases, Centers for Disease Control and Prevention, 3156 Rampart Road, Fort Collins, CO 80521 , USA

Tel + I 9702663535

Fax + I 9704946631

Email apowers@cdc.gov
Abstract: Chikungunya virus (CHIKV) is a mosquito-borne virus that is associated with severe and prolonged arthralgia. Starting in 2004, CHIKV reemerged in a series of outbreaks along the east coast of Africa and on several islands of the Indian Ocean. Over the subsequent 10 years, the virus spread throughout the globe and caused over three million cases. Molecular characterization of the genomes over time revealed changes that were associated with changes in epidemiology and transmission patterns. Monitoring and exploitation of these changes may lead to better understanding of viral movement and potential options for prevention and control.

Keywords: chikungunya, alphaviral evolution, molecular epidemiology, transmission, outbreaks

\section{CHIKV biology and transmission}

Chikungunya virus (CHIKV) is one of 31 viruses within the family Togaviridae, genus Alphavirus. ${ }^{1}$ Like all alphaviruses, it has a single-stranded, positive-sense RNA genome of approximately $11.7 \mathrm{~kb}$ in length. ${ }^{2,3}$ The genome contains two open-reading frames. The first comprises the upstream two-thirds of the genome and encodes for the four nonstructural proteins. These proteins are involved in genome replication and are not associated with the intact virions. The structural proteins are generated from a subgenomic mRNA that is collinear with the $3^{\prime}$ one-third of the genome. These proteins encapsidate the nascent genomic RNA and include the surface glycoproteins responsible for viral binding and cellular entry. ${ }^{4}$

CHIKV is a zoonotic pathogen and is maintained in a cycle comprising forestdwelling mosquito vectors (primarily of the subgenus Aedes (Stegomyia)) and vertebrate reservoirs. ${ }^{5}$ The most commonly associated enzootic mosquito vectors are Aedes furcifer, Aedes luteocephalus, and Aedes africanus. ${ }^{5}$ Outside of Africa, the only mosquito species associated with CHIKV are Aedes aegypti, Aedes albopictus, and most recently, Aedes hensilli, all of which have been linked to outbreaks of CHIKV. ${ }^{6}$ Nonhuman primates are thought to be the primary reservoir in Africa, but it is postulated that other mammals such as rodents are also likely involved in zoonotic maintenance. ${ }^{7-9}$ Humans become infected when they enter the forest habitat and are bitten by an infected mosquito. Movement of an infected human from the forested areas to peri-urban or urban ecologies results in outbreak conditions where a human-to-mosquito-to-human cycle can result (Figure 1). It is interesting to note that no zoonotic maintenance cycle has ever been definitively identified in Asia, although a recent study in Malaysia identified Asian genotype CHIKV in macaques. ${ }^{10}$ How the virus will be maintained in the new world 


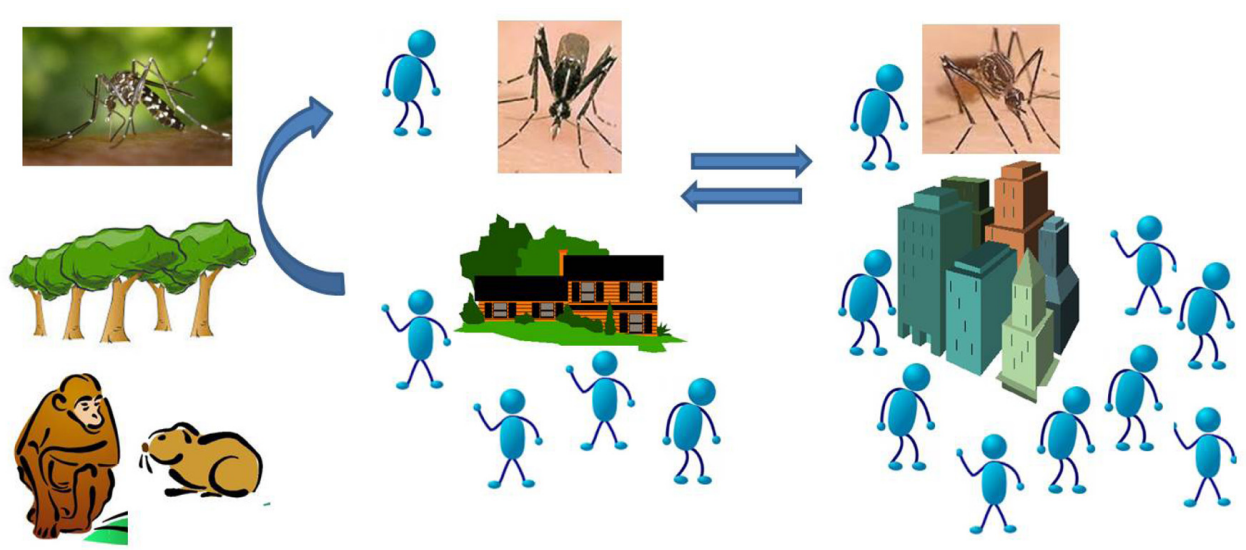

Figure I CHIKV is maintained zoonotically in a sylvatic cycle (left panel) between forest-dwelling Aedes sp mosquitoes and vertebrate reservoirs (like nonhuman primates and other small mammals).

Notes: An individual becomes infected when he/she enters this habitat and is bitten by an infected mosquito. When the individual returns to a rural or peri-urban habitat (center panel), Aedes albopictus and/or Aedes aegypti can transmit the virus between people causing limited, isolated cases of human disease. Large outbreaks occur when individuals or mosquitoes move to urban centers (right panel) where attack rates can reach over $60 \%$ and Ae. aegypti is typically the predominant vector.

Abbreviation: CHIKV, Chikungunya virus.

is currently unknown and a subject of extensive speculation. There are approximately 200 known species and subspecies of New World primates ${ }^{11}$ but no published information regarding how CHIKV might behave in these vertebrates.

\section{CHIKV clinical presentation}

Human infection with CHIKV was historically reported as resulting in a "mild, febrile illness". However, given the tremendous amount of recent human illness (over three million cases in the past decade), it has become clear that infection results in a highly debilitating disease that leaves patients incapacitated for up to weeks or months with severe polyarthralgia. Cases of chronic rheumatism have even been reported years after the original infection, although the frequency of these chronic cases and an understanding of how viral strain may impact long-term disease are still unclear. Infection typically begins with the rapid onset of a high fever $\left(>102^{\circ} \mathrm{F}\right)$ followed by development of severe joint pain bilaterally in the peripheral small joints. ${ }^{12}$ The onset of symptoms typically occurs within 3-7 days postinfection. An estimated $90 \%$ of patients present with these two symptoms and may or may not exhibit a range of other signs/symptoms including rash, myalgia, headache, or conjunctivitis. ${ }^{12}$ Historically, rash was considered one of three primary symptoms, but recent outbreaks have demonstrated significant variability in the percent of patients with rash. ${ }^{13,14}$ When it is present, it is typically maculopapular, but vesiculobullous or vasculitic skin lesions have also been reported, particularly in infants. ${ }^{15,16}$ In a small percentage of patients, atypical manifestations occur. These can include ocular lesions, neurological manifestations, or myocarditis. ${ }^{17-25}$ These more severe presentations usually occur in the elderly or very young. Overall, the disease is typically self-limiting, but for those with chronic joint pain, therapeutic options are needed but currently unavailable. Because so many of the clinical symptoms could also be associated with other common infections (eg, dengue, malaria, measles), laboratory diagnosis is needed for etiologic confirmation. For acute samples, nucleic acid detection is the method of choice as CHIKV generates high-titered viremias, and serum samples collected within a week of illness onset can provide a rapid positive diagnosis. Serological methods are used for non-acute specimens or to detect seroconversion. ${ }^{12}$ However, test quality can vary widely requiring careful selection of protocols and monitoring of control samples. ${ }^{26}$

\section{Molecular epidemiology and the continued reemergence of CHIKV}

While the western world has become more aware of CHIKV only during the past decade, the virus has been causing large epidemics since the 1950s. First identified in 1952 during an outbreak in modern day Tanzania, ${ }^{27}$ the virus spread from its origins in East Africa to India and Southeast (SE) Asia where major epidemics occurred affecting hundreds of thousands of people. In 1962-1964, a large urban outbreak was documented in Bangkok, Thailand. ${ }^{28,29}$ In 1962 alone, up to 70,000 pediatric cases of CHIKV were speculated to have occurred. A similarly large epidemic affecting approximately 400,000 people was reported during the same time period in Calcutta and Vellore, India ${ }^{30}$ with a second large Indian outbreak in the early 1970s in Maharashtra. ${ }^{31}$ After these large epidemics, periodic but smaller outbreaks 
of CHIKV were reported in both Africa and Asia over the next 30 years.

The ability to quickly and easily obtain genomic sequence of CHIKV during new emergence events became particularly useful in monitoring the movement of the virus. When the virus emerged during 2004 in coastal Kenya, sequence analysis rapidly demonstrated that the virus was of the Central/East African (or ECSA) genotype. This was not unexpected given the geographic location of the outbreak. Shortly after this Kenyan outbreak, sequences obtained from strains recovered from Comoros and La Reunion in 2005/2006 demonstrated that these island outbreaks were not new emergence events but rather a continuation and geographic expansion of the epidemics from Lamu and Mombassa. ${ }^{32}$ Similarly, as outbreaks erupted in India in 2005-2006, genetic data clearly revealed that the same lineage of virus identified on the islands of the Indian Ocean was found in India ${ }^{33}$ marking the rare event of the Central/East African genotype being identified outside of Africa. (A Central/East African strain had previously been found in a mosquito pool in India in 2000, but the origin of this strain was unclear. ${ }^{34}$ ) From India, due to the immense scope of the outbreak in this country $(>1.4$ million cases estimated in the first year alone ${ }^{35}$ ), the same lineage of virus was identified in a multitude of countries including Singapore, Sri Lanka, Malaysia, Bangladesh, Thailand, and in 2007, Italy. ${ }^{36-47}$ Complete genome analyses have led to the identification of unique mutations that came to be associated with particular geographic locales..$^{34,48-51}$ These specific mutations have further enabled the tracing of the virus movement and suggested possible routes of spread.

The massive and rapid spread of the virus generated significant public health interest in the virus, the result of which was increased surveillance for CHIKV, even in areas where cases were infrequent or had never previously been reported. Because of this intense interest, additional independent emergence events were identified. For example, in 2006, an outbreak was reported in Gabon with several thousand cases. Molecular characterization of strains from this event indicated that the virus was indeed of Central/ East African genotype but part of a distinct lineage from the one circulating broadly in India and SE Asia. ${ }^{52}$ Similarly, a study of factory workers in West Java in between 2000 and 2008 demonstrated that CHIKV was actively circulating in Indonesia. ${ }^{53}$ However, these cases were linked to the Asian genotype and supported the recognition that not only multiple lineages were circulating but also that the Asian genotype was being actively transmitted. An outbreak of Asian genotype was also reported in Malaysia during the same time period. ${ }^{44,54}$
This identification of movement and spread of the Asian genotype was unexpected given the widespread and rampant expansion of the Central/East African genotype throughout SE Asia. However, further evidence of the reemergence and spread of the Asian genotype was provided by the identification of Asian genotype CHIKV in New Caledonia in 2011. ${ }^{55}$ While fewer than 50 cases were reported during the initial emergence, the presence of this genotype in a region that had no prior record of autochthonous CHIKV activity was a clear indicator of the complex patterns of circulation and movement of various CHIKV lineages. Additional regional movement of the Asian genotype was documented by the identification of this genotype in Taiwan during 2006-2009, ${ }^{56}$ Singapore during 2008-2009, ${ }^{49}$ and the Philippines in 2012 2013. ${ }^{57}$ Further expansion of the Asian genotype occurred in 2013-2014 when a large outbreak occurred on the island of Yap in the Federated States of Micronesia (FSM) just east of the Philippines. ${ }^{58}$ Molecular analyses of the strains from Yap revealed a close relationship to sequences from the Philippines and from strains that were characterized in the People's Republic of China. ${ }^{59}$ This movement would not be unexpected given the geographic proximity and the degree of shipping interaction between FSM and these near neighbors. This outbreak was also significant in that it demonstrated the ability of additional Aedes (Stegomyia) subgenus species to cause epidemic CHIKV activity. ${ }^{60}$ Determination that additional Stegomyia vectors could mediate transmission during outbreaks became of further concern when the virus began to spread throughout numerous islands of the Pacific Ocean, many of which have populations of various Stegomyia sp mosquitoes. In 2014, CHIKV transmission was identified across the South Pacific in Tonga, American Samoa, Samoa, Tokelau, and French Polynesia ${ }^{61,62}$ where, in addition to $A e$. aegypti and Ae. albopictus, other regional Stegomyia sp such as Aedes polynesiensis, Aedes cooki, and Aedes tongae may play a role.

The most significant geographic expansion of CHIKV occurred with the detection of localized transmission of the virus in the Caribbean in the late 2013. Curiously, numerous travel-related cases were detected in the US, Canada, French Guiana, Brazil, and the Caribbean between 2006 and 2010, yet no autochthonous cases were identified during this time frame. ${ }^{63-66}$ The molecular characterization of the isolates from St Martin and Martinique revealed that the strains were of Asian genotype similar to those from Yap and the Philippines. ${ }^{67}$ Movement of the virus through the islands of the Caribbean occurred with stunning speed: just 1 year after the report of the first case, local transmission of the virus had 
occurred in 26 countries in the Caribbean, all seven countries in Central America, seven countries in South America, Mexico, and the US with nearly one million suspect or confirmed cases reported (Table 1). ${ }^{68}$ With the approach of the end of the 2014 rainy season, case numbers might be expected to fall, but with the extensive entrenchment of the virus in the Americas, it is highly probable that case numbers will resurge

Table I Countries with confirmed autochthonous CHIKV transmission in the Americas

\begin{tabular}{|c|c|c|}
\hline $\begin{array}{l}\text { Month and } \\
\text { year of first } \\
\text { report }\end{array}$ & Country/territory & $\begin{array}{l}\text { Cumulative } \\
\text { estimated } \\
\text { number of cases* }\end{array}$ \\
\hline \multirow[t]{5}{*}{ December 2013} & Guadeloupe & 80,962 \\
\hline & Martinique & 79,860 \\
\hline & St Barthelemy & $\mathrm{I}, 156$ \\
\hline & St Maarten & 425 \\
\hline & St Martin & 4,564 \\
\hline \multirow[t]{2}{*}{ January 2014} & British Virgin Islands & 44 \\
\hline & Dominica & 3,916 \\
\hline \multirow[t]{3}{*}{ February 2014} & Anguilla & 49 \\
\hline & French Guiana & 7,870 \\
\hline & St Kitts and Nevis & 459 \\
\hline March 2014 & Aruba & 230 \\
\hline \multirow[t]{4}{*}{ April 2014} & Antigua and Barbuda & 1,394 \\
\hline & Dominican Republic & 499,000 \\
\hline & St Lucia & 896 \\
\hline & St Vincent and the Grenadines & 494 \\
\hline \multirow[t]{3}{*}{ May 2014} & Guyana & 76 \\
\hline & Haiti & 64,709 \\
\hline & Puerto Rico & 20,073 \\
\hline \multirow[t]{4}{*}{ June 2014} & Grenada & 2,852 \\
\hline & Suriname & 1,210 \\
\hline & US Virgin Islands & 1,339 \\
\hline & Venezuela & 7,400 \\
\hline \multirow[t]{6}{*}{ July 2014} & Bahamas & 79 \\
\hline & Barbados & 1,427 \\
\hline & Costa Rica & I \\
\hline & Panama & 32 \\
\hline & Turks and Caicos & 19 \\
\hline & US & $\mathrm{II}$ \\
\hline \multirow[t]{4}{*}{ August 2014} & Cayman Islands & 25 \\
\hline & Curacao & 1,999 \\
\hline & Jamaica & 1,098 \\
\hline & Trinidad and Tobago & 177 \\
\hline \multirow[t]{2}{*}{ September 2014} & Brazil & 173 \\
\hline & Colombia & 22,372 \\
\hline \multirow[t]{4}{*}{ October 2014} & Guatemala & 473 \\
\hline & Honduras & 194 \\
\hline & Montserrat & 19 \\
\hline & Nicaragua & 542 \\
\hline \multirow[t]{4}{*}{ November 2014} & Belize & 3 \\
\hline & El Salvador & 123,229 \\
\hline & Mexico & 14 \\
\hline & Paraguay & I \\
\hline
\end{tabular}

Note: *Includes only cases reported to Pan American Health Organization as of November 21, 2014; includes both suspect and confirmed cases.

Abbreviation: CHIKV, Chikungunya virus. with the onset of the 2015 rains in early summer and that an enzootic state is likely to have been established.

\section{Microevolutionary events affecting mosquito transmission}

A highly noted single-amino acid change in the early Indian Ocean ECSA lineage was likely responsible for keeping the outbreak alive in La Reunion in 2006. Had this E1 glycoprotein change not been selected for, it is likely that the outbreak would have ended early in 2006 in La Reunion before significant movement of the virus to India and elsewhere due to the lack of highly efficient mosquito vectors on the island. In 2005, while the epidemic was raging on Comoros, there was only a trickle of cases in La Reunion. However, in early 2006, the number of cases exploded in La Reunion with an estimated 40,000 cases per week during the peak of the epidemic. Molecular genetic analyses of strains collected both before and after the increase in cases revealed a small number of amino acid changes that might have been involved in the shift in epidemiological patterns. ${ }^{69,70}$ Using infectious clone technology, individual point mutations were sequentially evaluated to determine the role of each change from early during the outbreak. One of these mutations, the now famous alanine-to-valine switch at E1 amino acid position 226, was found to increase the ability of the virus to infect Ae. albopictus mosquitoes; a difference of approximately $2 \log _{10}$ was found when comparing identical viruses containing changes only at this single locus. ${ }^{71}$ Interestingly, this particular mutation had little impact on the ability to infect Ae. aegypti. While this minor variant may have been present in the population for some time, the selection for the valine variant was significant in La Reunion due to the fact that Ae. albopictus was the predominant species identified, while the vector in Kenya and Comoros, Ae. aegypti, was only sparsely found in La Reunion. ${ }^{72,73}$ The presence of this mutation was of such importance for the virus's ability to utilize Ae. albopictus as a vector that microevolutionary genetic analysis suggested that this same mutation was likely to have emerged at least three times independently. ${ }^{74}$ After the La Reunion emergence, the same change was found after outbreaks began in India, Central Africa (Gabon/Cameroon), and Sri Lanka. All three countries have Ae. aegypti mosquitoes, but populations of Ae. albopictus were present and perhaps increasing as well, primarily due to changes in ecological habitats. ${ }^{75-79}$ Interestingly, in addition to this primary genetic change associated with altered vector usage, follow-up studies revealed additional mutations that could further enhance the vector competence of Ae. albopictus. ${ }^{80}$ Not all lineages identified contained these supporting 
mutations, but laboratory studies have demonstrated that vector competence could be easily modified with only minimal additional selection events. Laboratory studies examining the virus populations generated by mosquito anatomical barriers have also identified mutations that could arise because they confer fitness advantages to their host systems. ${ }^{81}$ These reports strongly support early monitoring of viruses emerging in new regions to provide timely information on viral variants that may affect transmission and epidemiology.

While modification of the ECSA genotype affected mosquito transmission of the virus in the Eastern hemisphere, no similar or other mutations have been identified in the Asian genotype lineage circulating in the Americas to date. Variation at the E1226 position has not been shown to affect transmissibility of the Asian genotype viruses, and numerous populations of both Ae. aegypti and Ae. albopictus from around the Americas have been shown to be quite competent for CHIKV transmission. ${ }^{55,82}$ Monitoring for additional genetic changes in the virus that could affect transmissibility of the virus in the Americas will be a priority activity.

\section{Identified mutations associated with altered virulence}

While there have been a number of studies focused on the microevolutionary changes that impacted the ability of CHIKV to interact with the mosquito vectors during the past decade, identifying mutations or processes that may affect pathogenesis or virulence in the human hosts has been more challenging. Limited recent studies have indicated that primary cellular targets of CHIKV infection are fibroblasts and osteoblasts; infection of these cells is associated with the musculoskeletal disease observed. ${ }^{83}$ The resulting infiltration of these tissues with inflammatory cells such as monocytes and macrophage is also believed to be associated with pathogenesis. Other immune system elements that have been found to be associated with CHIKV disease include several cytokines and chemokines such as interleukin-6, monocyte chemotactic protein 1 (MCP-1), and monokine induced by gamma interferon. ${ }^{84-88}$ Increased levels of each of these are linked to disease severity. However, the individual role of each of these elements has not yet been elucidated.

Because human studies are difficult to perform, significant efforts have been undertaken to develop suitable animal models for pathogenesis studies. Most of these models have focused on isolating particular elements of the immune response, and several have demonstrated a disease pattern of joint swelling and musculoskeletal injury similar to that seen in human patients. ${ }^{89-95}$ Use of mouse strains that are lacking in particular immune functions can aid in identifying the role of the immune system in pathogenesis. For example, infection of mice lacking mature B and T cells (Rag1-/-) results in reduced levels of joint swelling and less severe disease, ${ }^{96}$ and a similar phenomenon is found with mice lacking CD4+ T cells. ${ }^{97}$ Together, these results suggest a role for CD4+ T cells in disease progression.

Unfortunately, while there is some preliminary evidence for the role of various immune cells and factors in disease progression and severity, how individual genomic elements of the virus modulate disease is even less well characterized. The clearest data to delineate specific viral elements involved in virulence come from studies related to evaluation of vaccine strains. Comparison of the genome of the vaccine strain 181/25 with its virulent progenitor, AF15561, revealed two mutations that were implicated in viral attenuation. ${ }^{98}$ A more detailed study looking at the mechanism of this attenuation process suggested a role for binding to glycosaminoglycans which affected not only tissue tropism but also the related destruction that accompanies infection. In particular, a change of amino acid at E2 position 82 affected swelling, inflammation, and necrosis induced by infection. ${ }^{99}$ The authors found that an arginine in this position (as in the vaccine strain) reduced virulence, while replacing the arginine with a glycine as in the virulent AF15561 strain resulted in muscle destruction and more severe tendonitis. Interestingly, the presence of the arginine residue also affected the ability of the virus to replicate in lymphoid tissues. Given that this residue was originally presumed to be involved primarily in binding, ${ }^{89,100}$ these findings that this locus affects virulence merit further mechanistic studies. Even more research is needed with currently circulating epidemic strains to identify any viral elements in this lineage that may have the ability to impact the course of disease progression.

\section{Strategies for prevention and control}

The ultimate goal of obtaining information regarding specific viral data is that it would be helpful in controlling transmission of the virus. One potential control strategy is the utilization of a CHIKV-specific vaccine. A number of approaches have been utilized in this effort to design a highly efficacious vaccine including live-attenuated vaccines, virus-like particles, vector-based vaccine expression systems, DNA vaccines, and subunit vaccines. However, only three candidate products have yet to advance to clinical trials. The first was a live-attenuated variant developed by scientists at the Walter Reed Army Institute of Research and the US Army Medical Research Institute of Infectious Diseases by passaging a human isolate 
until an attenuated phenotype was achieved. ${ }^{101} \mathrm{~A}$ Phase II trial was completed on this candidate with $85 \%$ of the recipients maintaining CHIKV-specific antibodies at 1 year postvaccination. ${ }^{102}$ The second candidate is a virus-like particle (VLP) that, like its predecessor, stimulated a strong and long-lasting antibody profile but also had the advantage of increased safety because no live virus would ever be generated from this vaccine. ${ }^{103,104}$ The third clinically tested option is a recombinant measles/CHIKV system that incorporates the structural protein genes of CHIKV into a measles vector which results in the generation of CHIKV VLPs. ${ }^{105}$ While all of these candidates have shown promise in the early clinical trials, additional information regarding the mechanism of attenuation would be valuable. Understanding how particular epitopes or mutations result in attenuation would allow the development of more advanced vaccines with targeted control pathways. One such approach utilized the fact that live-attenuated arbovirus vaccines have the common feature of exhibiting an increased positive surface charge. A series of mutants with single-amino acid changes in the CHIKV E2 glycoprotein revealed a particular mutation that was attenuating via sensitivity to competition with the heparin sulfate analog, heparin. ${ }^{106}$ By using strategic targeting approaches to identify particular mutations associated with certain mechanisms of control, these individual elements can be combined to make safer, more stable vaccines that can act through multiple pathways.

This knowledge of mechanistic actions involved in the infection process is also important for the development of products for a second control strategy: antiviral compounds. With recent discoveries of the role of various immune system components, compounds targeting these specific immune pathways can be utilized. For example, knowing that MCP-1 is strongly induced upon infection with CHIKV, research involved in treatment of mice with the MCP inhibitor, bindarit, demonstrated elimination of disease symptoms and reduction in bone loss associated with infection. ${ }^{107,108}$ Another example targeting cellular proteins known to interact specifically with CHIKV proteins involves the small interfering RNA-mediated knockdown of HSP-90 transcripts; this limits the interaction of HSP-90 with CHIKV nsP3 or nsP4 and thus reduces the ability of the virus to replicate. ${ }^{109}$ Alternate immune-mediated approaches, such as monoclonal-antibody therapy, have the added advantage of specifically targeting CHIKV infection rather than modulation of the immune system as a whole. Monoclonal antibodies have been found to map to specific areas of the viral surface glycoproteins, blocking fusion and limiting entry into host cells. ${ }^{110,111}$ Because different monoclones have distinct epitope targets, combining multiple antibodies could generate a more effective therapy while minimizing the risk of antibody resistance. ${ }^{112}$ Finally, targeting very specific viral elements, such as viral genomic sequences using antiviral small interfering RNAs, could be an additional option for therapeutic control of infection. ${ }^{113}$ Because several of these options could be sensitive to viral adaptation to the treatment, a combination therapy may prove most promising for long-term control. Awareness of mutations arising in the CHIKV strains circulating in a population will also be critical for ensuring that any genome-specific antiviral strategies remain effective targets for control.

\section{Conclusion}

CHIKV has become one of the most prominent human disease-causing arboviruses. In just over 10 years, it moved from being an agent causing focal outbreaks in Africa and SE Asia/ India to a pandemic pathogen. Notably, increased risk factors associated with previously unaffected areas have facilitated the spread of this medically important arbovirus. ${ }^{114} \mathrm{CHIKV}$ has also become a symbol of the need to monitor emerging viruses for changes in their epidemiological capacity.

Advanced molecular detection tools have provided researchers and public health officials critical information regarding the movement patterns of the virus, changes in risk to populations due to altered vectorial capacity elements, and a wealth of potential vaccine and therapeutic options. These tools provide the means to significantly impact and reduce the scope of future outbreaks due to CHIKV. However, monitoring the microevolutionary changes is only the first necessary step in curtailing such emergence events. Partnerships between public health officials, vector control specialists, clinicians, government and academic researchers, and pharmaceutical companies to effectively utilize microevolutionary data are needed for successful interventions and long-term strategies for control of emerging pathogens such as CHIKV.

\section{Disclaimer}

The findings and conclusions in this report are those of the author only and do not necessarily reflect the views of the Centers for Disease Control and Prevention.

\section{Disclosure}

The author has no conflicts of interest to disclose.

\section{References}

1. Powers A, Huang H, Roehrig J, Strauss E, Weaver S. Togaviridae. In: King AMQ, Adams MJ, Carstens EB, Lefkowtiz EJ, editors. Virus Taxonomy: Ninth Report of the International Committee on Taxonomy of Viruses. Amsterdam: Elsevier Academic Press; 2012:1103-1110. 
2. Khan AH, Morita K, Parquet Md Mdel C, Hasebe F, Mathenge EG, Igarashi A. Complete nucleotide sequence of Chikungunya virus and evidence for an internal polyadenylation site. J Gen Virol. 2002;83(12): 3075-3084.

3. Powers AM, Brault AC, Tesh RB, Weaver SC. Re-emergence of chikungunya and o'nyong-nyong viruses: evidence for distinct geographical lineages and distant evolutionary relationships. J Gen Virol. 2000;81(2): 471-479.

4. Strauss EG, Strauss JH. Structure and replication of the alphavirus genome. In: Schlesinger S, Schlesinger M, editors. The Togaviruses and Flaviviruses. New York: Plenum Press; 1986:35-90.

5. Jupp PG, McIntosh BM. Chikungunya virus disease. In: Monath TP, editor. The Arbovirus: Epidemiology and Ecology. Vol II. Boca Raton, FL: CRC Press; 1988:137-157.

6. Savage HM, Ledermann JP, Yug L, Burkhalter KL, Marfel M, HancockWT. Incrimination of Aedes (Stegomyia) hensilli Farner as an Epidemic Vector of Chikungunya Virus on Yap Island, Federated States of Micronesia, 2013. Am J Trop Med Hyg. 2015;92(2):429-436.

7. Nakgoi K, Nitatpattana N, Wajjwalku W, et al. Dengue, Japanese encephalitis and Chikungunya virus antibody prevalence among captive monkey (Macaca nemestrina) colonies of Northern Thailand. Am J Primatol. 2014;76(1):97-102.

8. McIntosh BM. Susceptibility of some African wild rodents to infection with various arthropod-borne viruses. Transfusion (Paris). 1961;55: 63-68.

9. Boorman JP, Draper CC. Isolations of arboviruses in the Lagos area of Nigeria, and a survey of antibodies to them in man and animals. Trans R Soc Trop Med Hyg. 1968;62(2):269-277.

10. Apandi Y, Nazni WA, Noor Azleen ZA, et al. The first isolation of Chikungunya virus from nonhuman primates in Malaysia. J Gen Mol Virol. 2009;1:35-39.

11. Rylands AB, Mittermeier RA. The diversity of the newworld primates (Platyrrhini): an annotated taxonomy. In: Garber PA, Estrada A Bicca-Marques JC, Heymann EW, Strier KB, editors. South American Primates, Developments in Primatology: Progress and Prospects. New York: Springer Science+Business Media; 2009:23-54.

12. Staples JE, Breiman RF, Powers AM. Chikungunya fever: an epidemiological review of a re-emerging infectious disease. Clin Infect Dis. 2009;49(6):942-948.

13. Taubitz W, Cramer JP, Kapaun A, et al. Chikungunya fever in travelers: clinical presentation and course. Clin Infect Dis. 2007;45(1):e1-e4.

14. Queyriaux B, Simon F, Grandadam M, Michel R, Tolou H, Boutin JP. Clinical burden of Chikungunya virus infection. Lancet Infect Dis. 2008;8(1):2-3.

15. Inamadar AC, Palit A, Sampagavi VV, Raghunath S, Deshmukh NS. Cutaneous manifestations of chikungunya fever: observations made during a recent outbreak in south India. Int J Dermatol. 2008;47(2): 154-159.

16. Seetharam KA, Sridevi K, Vidyasagar P. Cutaneous manifestations of chikungunya fever. Indian Pediatr. 2012;49(1):51-53.

17. Ernould S, Walters H, Alessandri JL, et al. Aspects pédiatriques de l'épidémie de Chikungunya à l'île de la Réunion. [Chikungunya in paediatrics: epidemic of 2005-2006 in Saint-Denis, Reunion Island]. Arch Pediatr. 2008;15(3):253-262.

18. Wielanek AC, Monredon JD, Amrani ME, Roger JC, Serveaux JP. Guillain-Barre syndrome complicating a Chikungunya virus infection. Neurology. 2007;69(22):2105-2107.

19. Rampal SM, Meena H. Neurological complications in Chikungunya fever. J Assoc Physicians India. 2007;55:765-769.

20. Singh SS, Manimunda SP, Sugunan AP, Sahina P, Vijayachari P. Four cases of acute flaccid paralysis associated with Chikungunya virus infection. Epidemiol Infect. 2008;136(9):1277-1280.

21. Lalitha P, Rathinam S, Banushree K, Maheshkumar S, Vijayakumar R, Sathe P. Ocular involvement associated with an epidemic outbreak of Chikungunya virus infection. Am J Ophthalmol. 2007;144(4):552-556.

22. Mittal A, Mittal S, Bharati MJ, Ramakrishnan R, Saravanan S, Sathe PS Optic neuritis associated with Chikungunya virus infection in South India. Arch Ophthalmol. 2007;125(10):1381-1386.
23. Mittal A, Mittal S, Bharathi JM, Ramakrishnan R, Sathe PS. Uveitis during outbreak of chikungunya fever. Ophthalmology. 2007; 114(9): 1798 .

24. Obeyesekere I, Hermon Y. Myocarditis and cardiomyopathy after arbovirus infections (dengue and chikungunya fever). $\mathrm{Br}$ Heart $J$. 1972;34(8):821-827.

25. Obeyesekere I, Hermon Y. Arbovirus heart disease: myocarditis and cardiomyopathy following dengue and chikungunya fever - a follow-up study. Am Heart J. 1973;85(2):186-194.

26. Prat CM, Flusin O, Panella A, Tenebray B, Lanciotti R, Leparc-Goffart I. Evaluation of commercially available serologic diagnostic tests for Chikungunya virus. Emerg Infect Dis. 2014;20(12):2129-2132.

27. Ross RW. The Newala epidemic. III. The virus: isolation, pathogenic properties and relationship to the epidemic. J Hyg. 1956;54: 177-191.

28. Halstead SB, Scanlon JE, Umpaivit P, Udomsakdi S. Dengue and Chikungunya virus infection in man in Thailand, 1962-1964. IV. Epidemiologic studies in the Bangkok metropolitan area. Am J Trop Med Hyg. 1969;18(6):997-1021.

29. Halstead SB, Udomsakdi S, Scanlon JE, Rohitayodhin S. Dengue and Chikungunya virus infection in man in Thailand, 1962-1964. V. Epidemiologic observations outside Bangkok. Am J Trop Med Hyg. 1969;18(6):1022-1033.

30. Sakar JK, Chatterjee SN, Chakravarti SK, Mitra AC. Chikungunya virus infection with hemorrhagic manifestations. Ind J Med Res. 1965;53:921.

31. Padbidri VS, Gnaneswar TT. Epidemiological investigations of chikungunya epidemic at Barsi, Maharashtra state, India. J Hyg Epidemiol Microbiol Immunol. 1979;23(4):445-451.

32. Kariuki Njenga M, Nderitu L, Ledermann JP, et al. Tracking epidemic Chikungunya virus into the Indian Ocean from East Africa. J Gen Virol. 2008;89(11):2754-2760.

33. Yergolkar PN, Tandale BV, Arankalle VA, et al. Chikungunya outbreaks caused by African genotype, India. Emerg Infect Dis. 2006;12(10):1580-1583.

34. Arankalle VA, Shrivastava S, Cherian S, et al. Genetic divergence of Chikungunya viruses in India (1963-2006) with special reference to the 2005-2006 explosive epidemic. J Gen Virol. 2007;88(pt 7): 1967-1976.

35. Ravi V. Re-emergence of Chikungunya virus in India. Indian J Med Microbiol. 2006;24(2):83-84.

36. Angelini R, Finarelli AC, Angelini P, et al. An outbreak of chikungunya fever in the province of Ravenna, Italy. Euro Surveill. 2007;12(9): E070906070901.

37. Beltrame A, Angheben A, Bisoffi Z, et al. Imported chikungunya infection, Italy. Emerg Infect Dis. 2007;13(8):1264-1266.

38. Rezza G, Nicoletti L, Angelini R, et al; CHIKV Study Group. Infection with Chikungunya virus in Italy: an outbreak in a temperate region. Lancet. 2007;370(9602):1840-1846.

39. Leo YS, Chow AL, Tan LK, Lye DC, Lin L, Ng LC. Chikungunya outbreak, Singapore, 2008. Emerg Infect Dis. 2009;15(5):836-837.

40. Ng KW, Chow A, Win MK, et al. Clinical features and epidemiology of chikungunya infection in Singapore. Singapore Med J. 2009;50(8): 785-790.

41. Hapuarachchi HA, Bandara KB, Hapugoda MD, Williams S, Abeyewickreme W. Laboratory confirmation of dengue and chikungunya co-infection. Ceylon Med J. 2008;53(3):104-105.

42. Pongsiri P, Auksornkitti V, Theamboonlers A, Luplertlop N, Rianthavorn P, Poovorawan Y. Entire genome characterization of Chikungunya virus from the 2008-2009 outbreaks in Thailand. Trop Biomed. 2010;27(2):167-176.

43. Pulmanausahakul R, Roytrakul S, Auewarakul P, Smith DR. Chikungunya in Southeast Asia: understanding the emergence and finding solutions. Int J Infect Dis. 2011;15(10):e671-e676.

44. Kumarasamy V, Prathapa S, Zuridah H, Chem YK, Norizah I, Chua KB Re-emergence of Chikungunya virus in Malaysia. Med J Malaysia. 2006;61(2):221-225. 
45. AbuBakar S, Sam IC, Wong PF, MatRahim N, Hooi PS, Roslan N. Reemergence of endemic Chikungunya, Malaysia. Emerg Infect Dis. 2007;13(1):147-149.

46. Ayu SM, Lai LR, Chan YF, et al. Seroprevalence survey of Chikungunya virus in Bagan Panchor, Malaysia. Am J Trop Med Hyg. 2010;83(6): $1245-1248$.

47. ICDDR B. First identified outbreak of chikungunya in Bangladesh, 2008. Health Sci Bull. 2009;7:1.

48. Hapuarachchi HC, Bandara KB, Sumanadasa SD, et al. Re-emergence of Chikungunya virus in South-east Asia: virological evidence from Sri Lanka and Singapore. J Gen Virol. 2010;91(4):1067-1076.

49. Ng LC, Hapuarachchi HC. Tracing the path of Chikungunya virus evolution and adaptation. Infect Genet Evol. 2010;10(7):876-885.

50. Brisse S, Iteman I, Schuffenecker I. Chikungunya outbreaks. $N$ Engl $J$ Med. 2007;356(25):2650-2652.

51. Lu X, Li X, Mo Z, et al. Chikungunya emergency in China: microevolution and genetic analysis for a local outbreak. Virus Genes. 2014;48(1): 15-22.

52. Peyrefitte CN, Bessaud M, Pastorino BA, et al. Circulation of Chikungunya virus in Gabon, 2006-2007. J Med Virol. 2008;80(3): 430-433.

53. Kosasih H, de Mast Q, Widjaja S, et al. Evidence for endemic Chikungunya virus infections in Bandung, Indonesia. PLoS Negl Trop Dis. 2013;7(10):e2483.

54. Sam IC, Chan YF, Chan SY, et al. Chikungunya virus of Asian and Central/East African genotypes in Malaysia. J Clin Virol. 2009;46(2): 180-183.

55. Dupont-Rouzeyrol M, Caro V, Guillaumot L, et al. Chikungunya virus and the mosquito vector Aedes aegypti in New Caledonia (South Pacific Region). Vector Borne Zoonotic Dis. 2012;12(12):1036-1041.

56. Huang JH, Yang CF, Su CL, et al. Imported Chikungunya virus strains, Taiwan, 2006-2009. Emerg Infect Dis. 2009;15(11):1854-1856.

57. Kawashima KD, Suarez LA, Labayo HK, et al. Complete genome sequence of Chikungunya virus isolated in the Philippines. Genome Announc. 2014;2:3.

58. Hubner R. PRO/EDR> Chikungunya (04): Micronesia (YA) 2013 [ProMED mail correspondence]. 2013; Archive Number: 20140114.2171369. Available from: http://www.promedmail.org/direct. php?id=20140114.2171369. Accessed February 13, 2015.

59. Lanciotti R, Valadere A. Transcontinental movement of Asian genotype Chikungunya virus. Emerg Infect Dis. 2014;20:8.

60. Ledermann JP, Guillaumot L, Yug L, et al. Aedes hensilli as a potential vector of chikungunya and Zika viruses. PLoS Negl Trop Dis. 2014;8(10): 3188

61. Cao-Lormeau VM, Musso D. Emerging arboviruses in the Pacific. Lancet. 2014;384(9954):1571-1572.

62. Roth A, Mercier A, Lepers C, et al. Concurrent outbreaks of dengue, chikungunya and Zika virus infections - an unprecedented epidemic wave of mosquito-borne viruses in the Pacific 2012-2014. Euro Surveill. 2014;19:41.

63. Girod R, Gaborit P, Marrama L, et al. High susceptibility to Chikungunya virus of Aedes aegypti from the French West Indies and French Guiana. Trop Med Int Health. 2011;16(1):134-139.

64. Gibney KB, Fischer M, Prince HE, et al. Chikungunya fever in the United States: a fifteen year review of cases. Clin Infect Dis. 2011;52(5): e121-e126.

65. Chaves Tdo S, Pellini AC, Mascheretti M, et al. Travelers as sentinels for chikungunya fever, Brazil. Emerg Infect Dis. 2012;18(3): 529-530.

66. Schwartz KL, Giga A, Boggild AK. Chikungunya fever in Canada: fever and polyarthritis in a returned traveller. CMAJ. 2014;186(10): $772-774$.

67. Leparc-Goffart I, Nougairede A, Cassadou S, Prat C, de Lamballerie X. Chikungunya in the Americas. Lancet. 2014;383(9916):514.

68. PAHO. Chikungunya. Number of Reported Cases of Chikungunya Fever in the Americas; 2014. Available from: http://www.paho.org/hq/index. php?option $=$ com_content $\& v i e w=$ article $\& i d=9053 \& I t e m i d=40695 \& l a$ $\mathrm{ng}=\mathrm{en}$.
69. Schuffenecker I, Iteman I, Michault A, et al. Genome microevolution of Chikungunya viruses causing the Indian Ocean outbreak. PLoS Med. 2006;3(7):e263.

70. Vazeille M, Moutailler S, Coudrier D, et al. Two Chikungunya isolates from the outbreak of La Reunion (Indian Ocean) exhibit different patterns of infection in the mosquito, Aedes albopictus. PLoS One. 2007;2(11):e1168.

71. Tsetsarkin KA, Vanlandingham DL, McGee CE, Higgs S. A single mutation in Chikungunya virus affects vector specificity and epidemic potential. PLoS Pathog. 2007;3(12):e201.

72. Sang RC, Ahmed O, Faye O, et al. Entomologic investigations of a Chikungunya virus epidemic in the Union of the Comoros, 2005. Am J Trop Med Hyg. 2008;78(1):77-82

73. Reiter P, Fontenille D, Paupy C. Aedes albopictus as an epidemic vector of Chikungunya virus: another emerging problem? Lancet Infect Dis. 2006;6(8):463-464.

74. de Lamballerie X, Leroy E, Charrel RN, Ttsetsarkin K, Higgs S, Gould EA. Chikungunya virus adapts to tiger mosquito via evolutionary convergence: a sign of things to come? Virol J. 2008;5:33.

75. Bagny L, Delatte H, Quilici S, Fontenille D. Progressive decrease in Aedes aegypti distribution in Reunion Island since the 1900s. J Med Entomol. 2009;46(6):1541-1545.

76. Bagny Beilhe L, Delatte H, Juliano SA, Fontenille D, Quilici S. Ecological interactions in Aedes species on Reunion Island. Med Vet Entomol. 2013;27(4):387-397.

77. Paupy C, Delatte H, Bagny L, Corbel V, Fontenille D. Aedes albopictus, an arbovirus vector: From the darkness to the light. Microbes Infect. 2009;11(14-15):1177-1185.

78. Delatte H, Dehecq JS, Thiria J, Domerg C, Paupy C, Fontenille D. Geographic distribution and developmental sites of Aedes albopictus (Diptera: Culicidae) during a Chikungunya epidemic event. Vector Borne Zoonotic Dis. 2008;8(1):25-34.

79. Ramasamy R, Surendran SN, Jude PJ, Dharshini S, Vinobaba M. Larval development of Aedes aegypti and Aedes albopictus in peri-urban brackish water and its implications for transmission of arboviral diseases. PLoS Negl Trop Dis. 2011;5(11):e1369.

80. Tsetsarkin KA, McGee CE, Volk SM, Vanlandingham DL, Weaver SC, Higgs S. Epistatic roles of E2 glycoprotein mutations in adaption of Chikungunya virus to Aedes albopictus and ae. Aegypti mosquitoes. PLoS One. 2009;4(8):e6835.

81. Stapleford KA, Coffey LL, Lay S, et al. Emergence and transmission of arbovirus evolutionary intermediates with epidemic potential. Cell Host Microbe. 2014;15(6):706-716.

82. Vega-Rua A, Zouache K, Girod R, Failloux AB, Lourenco-de-Oliveira R. High level of vector competence of Aedes aegypti and Aedes albopictus from ten American countries as a crucial factor in the spread of Chikungunya virus. J Virol. 2014;88(11):6294-6306.

83. Morrison TE. Reemergence of Chikungunya virus. JVirol. 2014;88(20): 11644-11647.

84. Reddy V, Mani RS, Desai A, Ravi V. Correlation of plasma viral loads and presence of Chikungunya IgM antibodies with cytokine/ chemokine levels during acute Chikungunya virus infection. $J$ Med Virol. 2014;86(8):1393-1401.

85. Chirathaworn C, Poovorawan Y, Lertmaharit S, Wuttirattanakowit N. Cytokine levels in patients with Chikungunya virus infection. Asian Pacific J Trop Med. 2013;6(8):631-634.

86. Lohachanakul J, Phuklia W, Thannagith M, Thonsakulprasert T, Ubol S. High concentrations of circulating interleukin- 6 and monocyte chemotactic protein-1 with low concentrations of interleukin-8 were associated with severe chikungunya fever during the 2009-2010 outbreak in Thailand. Microbiol Immunol. 2012;56(2):134-138.

87. Kelvin AA, Banner D, Silvi G, et al. Inflammatory cytokine expression is associated with Chikungunya virus resolution and symptom severity. PLoS Negl Trop Dis. 2011;5(8):e1279.

88. Chow A, Her Z, Ong EK, et al. Persistent arthralgia induced by Chikungunya virus infection is associated with interleukin-6 and granulocyte macrophage colony-stimulating factor. $J$ Infect Dis. 2011;203(2): 149-157. 
89. Gardner CL, Burke CW, Higgs ST, Klimstra WB, Ryman KD. Interferon-alpha/beta deficiency greatly exacerbates arthritogenic disease in mice infected with wild-type Chikungunya virus but not with the cell culture-adapted live-attenuated 181/25 vaccine candidate. Virology. 2012;425(2):103-112.

90. Couderc T, Chrétien F, Schilte C, et al. A mouse model for Chikungunya: young age and inefficient type-I interferon signaling are risk factors for severe disease. PLoS Pathog. 2008;4(2):e29.

91. Ziegler SA, Lu L, da Rosa AP, Xiao SY, Tesh RB. An animal model for studying the pathogenesis of Chikungunya virus infection. Am J Trop Med Hyg. 2008;79(1):133-139.

92. Gardner J, Anraku I, Le TT, et al. Chikungunya virus arthritis in adult wild-type mice. J Virol. 2010;84(16):8021-8032.

93. Morrison TE, Oko L, Montgomery SA, et al. A mouse model of Chikungunya virus-induced musculoskeletal inflammatory disease: evidence of arthritis, tenosynovitis, myositis, and persistence. $\mathrm{Am} \mathrm{J}$ Pathol. 2011;178(1):32-40.

94. Patil DR, Hundekar SL, Arankalle VA. Expression profile of immune response genes during acute myopathy induced by Chikungunya virus in a mouse model. Microbes Infect. 2012;14(5):457-469.

95. Dagley A, Julander JG. A mouse model of Chikungunya virus with utility in antiviral studies. Methods Mol Biol. 2013;1030:439-448.

96. Hawman DW, Stoermer KA, Montgomery SA, et al. Chronic joint disease caused by persistent Chikungunya virus infection is controlled by the adaptive immune response. J Virol. 2013;87(24):13878-13888.

97. Teo TH, Lum FM, Claser C, et al. A pathogenic role for CD4+ T cells during Chikungunya virus infection in mice. J Immunol. 2013; 190(1):259-269.

98. Gorchakov R, Wang E, Leal G, et al. Attenuation of Chikungunya virus vaccine strain 181/clone 25 is determined by two amino acid substitutions in the E2 envelope glycoprotein. J Virol. 2012;86(11): 6084-6096.

99. Ashbrook AW, Burrack KS, Silva LA, et al. Residue 82 of the Chikungunya virus E2 attachment protein modulates viral dissemination and arthritis in mice. J Virol. 2014;88(21):12180-12192.

100. Silva LA, Khomandiak S, Ashbrook AW, et al. A single-amino-acid polymorphism in Chikungunya virus E2 glycoprotein influences glycosaminoglycan utilization. J Virol. 2014;88(5):2385-2397.

101. Levitt NH, Ramsburg HH, Hasty SE, Repik PM, Cole FE Jr, Lupton HW. Development of an attenuated strain of Chikungunya virus for use in vaccine production. Vaccine. 1986;4(3):157-162.

102. Edelman R, Tacket CO, Wasserman SS, Bodison SA, Perry JG, Mangiafico JA. Phase II safety and immunogenicity study of live Chikungunya virus vaccine TSI-GSD-218. Am J Trop Med Hyg. 2000;62(6):681-685.
103. Powers AM. Chikungunya virus control: is a vaccine on the horizon? Lancet. 2014;384(9959):2008-2009.

104. Chang LJ, Dowd KA, Mendoza FH, et al; VRC 311 Study Team. Safety and tolerability of Chikungunya virus-like particle vaccine in healthy adults: a phase 1 dose-escalation trial. Lancet. 2014;384(9959): 2046-2052.

105. Brandler S, Ruffié C, Combredet C, et al. A recombinant measles vaccine expressing Chikungunya virus-like particles is strongly immunogenic and protects mice from lethal challenge with Chikungunya virus. Vaccine. 2013;31(36):3718-3725

106. Gardner CL, Hritz J, Sun C, et al. Deliberate attenuation of Chikungunya virus by adaptation to heparan sulfate-dependent infectivity: a model for rational arboviral vaccine design. PLoS Negl Trop Dis. 2014;8(2):e2719

107. Rulli NE, Rolph MS, Srikiatkhachorn A, Anantapreecha S, Guglielmotti A, Mahalingam S. Protection from arthritis and myositis in a mouse model of acute Chikungunya virus disease by bindarit, an inhibitor of monocyte chemotactic protein-1 synthesis. J Infect Dis. 2011;204(7):1026-1030

108. Chen W, Foo SS, Taylor A, et al. Bindarit, an inhibitor of monocyte chemotactic proteins (MCPs) synthesis, protects against bone loss induced by Chikungunya virus infection. J Virol. 2015;89(1) 581-593.

109. Rathore AP, Haystead T, Das PK, Merits A, Ng ML, Vasudevan SG. Chikungunya virus nsP3 and nsP4 interacts with HSP-90 to promote virus replication: HSP-90 inhibitors reduce CHIKV infection and inflammation in vivo. Antiviral Res. 2014;103:7-16.

110. Pal P, Dowd KA, Brien JD, et al. Development of a highly protective combination monoclonal antibody therapy against Chikungunya virus. PLoS Pathog. 2013;9(4):e1003312.

111. Selvarajah S, Sexton NR, Kahle KM, et al. A neutralizing monoclonal antibody targeting the acid-sensitive region in Chikungunya virus E2 protects from disease. PLoS Negl Trop Dis. 2013;7(9):e2423.

112. Pal P, Fox JM, Hawman DW, et al. Chikungunya viruses that escape monoclonal antibody therapy are clinically attenuated, stable, and not purified in mosquitoes. J Virol. 2014;88(15):8213-8226.

113. Parashar D, Paingankar MS, Kumar S, et al. Administration of E2 and NS1 siRNAs inhibit Chikungunya virus replication in vitro and protects mice infected with the virus. PLoS Negl Trop Dis. 2013;7(9) e2405.

114. Powers AM. Risks to the Americas Associated with the Continued Expansion of Chikungunya Virus. J Gen Virol. 2015;96(1):1-5.
Research and Reports in Tropical Medicine

\section{Publish your work in this journal}

Research and Reports in Tropical Medicine is an international, peerreviewed, open access journal publishing original research, case reports, editorials, reviews and commentaries on all areas of tropical medicine, including: Diseases and medicine in tropical regions; Entomology; Epidemiology; Health economics issues; Infectious disease; Laboratory

\section{Dovepress}

science and new technology in tropical medicine; Parasitology; Public health medicine/health care policy in tropical regions; and Microbiology. The manuscript management system is completely online and includes a very quick and fair peer-review system. Visit http://www.dovepress. com/testimonials.php to read real quotes from published authors. 